Asia Proceedings of Social Sciences

(APSS)

www.readersinsight.net/APSS

\title{
The Factors that Influence Tax Avoidance in Companies Listing on the Indonesia Stock Exchange
}

\section{Popi Fauziati*}

Accounting Departement, Faculty of Economics, Universitas Bung Hatta Indonesia

Faculty of Business and Accountancy, Universiti Selangor, Malaysia

\section{Yunilma}

Accounting Departement, Faculty of Economics, Universitas Bung Hatta Indonesia

\section{Musdalifah Dimuk}

Faculty of Business and Accountancy, Universiti Selangor, Malaysia

\section{Neva Nevianti}

Accounting Departement, Faculty of Economics, Universitas Bung Hatta Indonesia

\section{Nurul Nisa lby}

Accounting Departement, Faculty of Economics, Universitas Bung Hatta Indonesia

*Corrosponding author's Email: popifauziati@bunghatta.ac.id

Peer-review under responsibility of $4^{\text {th }}$ Asia International Conference 2018 editorial board (http://www.utm.my/asia/our-team/) (C) 2018 Published by Readers Insight Publisher, lat 306 Savoy Residencia, Block 3 F11/1,44000 Islamabad. Pakistan, info@ readersinsight.net 


\section{Research High Iight s}

Tax avoidance is accomplished by intelligent analysis and choice of tax impact and by taking advantage of faults and loopholes in the existing tax laws. This study examines the factors that influence tax avoidance. There are three hypotheses that will be tested in this study and the results show that showing that accounting quality and conservatism does not affect tax avoidance while sales growth has an effect on tax avoidance.

\section{Research Objectives}

This study purpose to examine the influence of audit quality, accounting conservarism and sales growth on tax avoidance. According to Annisa and Kurniasih (2012) audit quality has a significant effect on tax avoidance. So if a company is audited by the Public Accounting Firm (KAP), the Big Four will find it increasingly difficult to do tax avoidance. Sundari and Aprilina (2017) shows that accounting conservatism significantly influences tax avoidance. Conservative accounting has an impact in the form of decreasing company profits / profits as a basis for calculating the company's tax obligations. This shows that the more conservative a financial report, the tax avoidance action will be even greater. Kim and Im (2017) shows that sales growth has a significant effect on tax avoidance. The higher the sales growth of the company, the greater the probability that the company's profits will be large. If the profits generated by large companies, then the company will do better tax planning. Therefore, the possibility of companies to take tax avoidance actions will be low.

\section{Methodology}

This study uses data from the listed companies producing raw materials / natural resource processing industries during 2012-2017 on the Indonesia Stock Exchange. The purposive sampling method is used in conducting sample selection using the criteria: The company does not suffer losses, publishes financial statements in rupiah currency and has a CETR $<1$ value during 2012-2017. Measurement of tax avoidance in this study uses the Effective Cash Tax Rate (CETR) model, audit quality is measured by a dummy variable where the company 


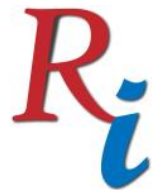

\section{Asia Proceedings of Social Sciences \\ (APSS) \\ www.readersinsight.net/APSS}

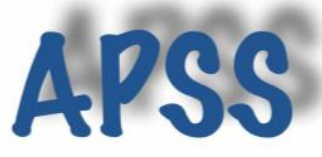

audited by the Big Four will be given 1, and if not audited by the Big Four will be given a value of 0 . Accounting conservatism variable measured using accruals when accruals are negative, indicating that the adoption of accounting conservatism and sales growth is measured by means of the final sales period reduced by the initial sales period and divided by the initial sales period.

\section{Results}

This research uses 12 raw material producing companies / natural resource processing industries. The results of data analysis show that audit quality, accounting conservatism and sales growth affect tax avoidance by $19.8 \%$. The variable that influences tax avoidance is sales growth. The results of this study are consistent with the results of Kim \& Im (2017) but are not consistent with Swingly \& Sukartha (2015) and Oktaviyani \& Munandar (2017). Audit quality and accounting conservatism do not affect tax avoidance. This result is consistent with Sundari \& Aprilina (2017) and Sarra (2017) but not consistent with Kim \& Kim (2013), Tendean \& Winnie (2016), Anissa \& Kurniasih et al (2017).

\section{Findings}

Audit quality does not affect tax avoidance because the audit conducted by KAP is more focused on financial report audits. Where the financial statement audit aims to determine whether the financial statements presented by the company are in accordance with the Financial Accounting Standards or generally accepted accounting, not to measure the presence or absence of fraud committed by companies, especially fraud in taxation, one of which is tax avoidance. The use of conservative accounting methods cannot increase the tendency of companies to carry out tax avoidance, because with the existence of government regulations, the tendency to do tax avoidance will be narrower. The higher level of sales growth will result in the smaller tax avoidance activities of a company, which is caused by companies with relatively high levels of sales will provide opportunities to earn large profits and be able to pay taxes. Therefore, the possibility of companies doing tax avoidance is getting lower. 


\section{Asia Proceedings of Social Sciences \\ (APSS) \\ www.readersinsight.net/APSS}

\section{References}

Annisa, A.N., \& Kurniasih, L. (2012). Pengaruh Corporate Governance terhadap Tax Avoidance. Jurnal Akuntansi dan Auditing Vol. 8 No. 2/Mei 2012: 95-189.

Kim, J.H., \& Im, C.C., (2017). The Study On The Effect And Determinants Of Small - And Medium-Sized Entities Conducting Tax Avoidance. The Journal of Applied Business Research - March/April 2017 Volume 33, Number 2.

Oktaviyani, R. \& Munandar, A. (2017). Effect of Solvency, Sales Growth, and Institutional Ownership on Tax Avoidance with Profitability as Moderating Variables in Indonesian Property and Real Estate Companies. Binus Business Review, 8(3), November 2017, 183-188 ISSN: 2087-1228 E-ISSN: 24769053.

Sarra, D. H. (2017). Pengaruh Konservatisme Akuntansi, Komite Audit dan Dewan Komisaris Independen Terhedap Penghindaran pajak. Competitive, Vol. 1 No. 1, Januari-Juni 2017.

Sundari, N. \& Aprilina, V. (2017). Pengaruh Konservatisme Akuntansi, Intensitas Aset Tetap, Kompensasi Rugi Fiskal dan Corporate Governanace Terhadap Tax Avoidance. JRAK Vol.8 No.1 Februari 2017

Swingly, C. \& Sukartha, I. M. (2015). Pengaruh Karakter Eksekutif, Komite Audit, Ukuran Perusahaan, Leverage Dan Sales growth Pada Tax Avoidance. E-Jurnal Akuntansi Universitas Udayana 10.1 (2015): 47-62 ISSN: 2302-8556 . 